\title{
QUE VENHAM OS IMIGRANTES! - CRISE POLÍTICA E QUESTÃO IMIGRATÓRIA EM MINAS GERAIS E RIO DE JANEIRO NO ALVORECER DA REPÚBLICA ${ }^{1}$
}

\author{
Maria Isabel de Jesus Chrysostomo \\ Programa de Pós-Graduação em Geografia \\ Universidade Federal de Viçosa (UFV), Viçosa/MG \\ isachrysostomo@ufv.br
}

Higor Mozart Geraldo Santos Universidade do Estado de Minas Gerais (UEMG/Carangola) Doutorando em Geografia - Universidade Federal Fluminense (UFF), Niterói/RJ hmozart@gmail.com

\begin{abstract}
RESUMO
Discutimos como o clima de instabilidade política, incitado pela crise da lavoura e ascensão política de São Paulo, mobilizou discursos de autoridades fluminenses e mineiras em fins dos oitocentos. Com o intuito de promover a imigração e potencializar os "dons" presentes em suas unidades federativas, os argumentos arrolados assumiram tom geopolítico ao entrelaçar política, território e natureza. A imigração estrangeira converte-se, nesse jogo de representações, em importante arma empunhada para resgatar o prestígio político dos respectivos estados e promover o seu desenvolvimento econômico. Em um primeiro momento, realçamos o papel político das migrações no começo da República com objetivo de assinalar seus efeitos espaciais. Na esteira, problematizamos como Minas Gerais e Rio de Janeiro forjavam representações espaciais, via discurso regional e local, com o intento de atrair imigrantes estrangeiros. Ao final, sublinhamos, de forma comparativa, as principais estratégias territoriais das elites mineiras e fluminenses para superar a alegada crise em seus respectivos estados.
\end{abstract}

Palavras-chave: Política imigratória. Discursos geográficos. Minas Gerais. Rio de Janeiro.

\section{Let the immigrants come! - Political crisis and immigration issue in Minas Gerais and Rio de Janeiro at the dawn of the Republic}

\begin{abstract}
It was discussed how the climate of political instability, incited by the crop crisis and the political rise of São Paulo, mobilized speeches by Rio de Janeiro and Minas Gerais authorities in the late 1800s. In order to promote immigration and enhance the "gifts" present in their federative units, the arguments adopted took on a geopolitical tone when intertwining politics, territory and nature. In this game of representations, foreign immigration becomes an important weapon used to rescue the political prestige of the respective states and promote their economic development. At first, it was emphasized the political role of migrations in the beginning of the Republic in order to highlight their spatial effects. In this sense, it was problematized how Minas Gerais and Rio de Janeiro forged spatial representations via regional and local discourse with the intention of attracting foreign immigrants. In the end, it was underlined, in a comparative way, the main territorial strategies of the Minas Gerais and Rio de Janeiro elites to overcome the alleged crisis in their respective states.
\end{abstract}

Keywords: Immigration policy. Geographical discourses. Minas Gerais. Rio de Janeiro.

\footnotetext{
${ }^{1} \mathrm{O}$ presente trabalho é produto do desenvolvimento do projeto de pesquisa "O imigrante em disputa: o lugar e o território do estrangeiro nos conflitos regionais entre Minas Gerais e Rio de Janeiro nos anos 1870-1930", financiado pelo CNPQ (Processo APQ 429204/20167) e FAPEMIG (Processo APQ-00658-15) e coordenado pela Autora. 


\section{INTRODUÇÃO}

O objetivo central dessa reflexão é situar a política de imigração estrangeira como uma política territorial de grande envergadura. Em nossa investigação indagamos se o projeto imigratório não teria sido mais um componente essencial das disputas regionais que envolviam, sobretudo, Rio de Janeiro e Minas Gerais no começo da República. Para compreender nuances desse processo elegemos um roteiro investigativo que contempla os caminhos teóricos e metodológicos da geografia histórica.

Enfrentamos, assim, como Maurício Abreu (1997), o desafio de discriminar no passado o "então presente", ao utilizar toda sorte de ferramentas metodológicas para ler e interpretar nos registros materiais, o que o tempo suplantou. Dessa forma, a questão imigratória, é vista a partir dos dilemas presentes e analisada através das materializações impregnadas nas paisagens pretéritas. Enxergar, discriminar e datar estas materialidades tornou-se um dos principais desafios na medida em que expressam a complexidade do processo de produção das formas geográficas.

Para compreender como o processo migratório assumiu "formas geográficas" seguimos o exemplo de Santos (2006): encaramos como sínteses do tempo-espaço, os diversos dispositivos técnicos, estrategicamente implantados de forma desigual na paisagem. À luz dessa perspectiva, o caminho seguinte foi distinguir e classificar, no começo da República, tais dispositivos nos então considerados "períodos densos" e nos "hiatos temporais"2; ou seja, identificar quais as foram as formas geográficas produzidas em um período mais largo que interferiam direta e indiretamente na questão imigratória e aquelas que se associavam aos eventos de curta duração, mas que eram determinantes. A ideia de estreitar o diálogo entre a geografia e a história, a partir da questão migratória, é nesse trabalho o nosso principal propósito.

Por meio das pistas encontradas em documentos, nos atrevemos a construir uma forma de interpretação sobre o papel das migrações e a política de colonização no passado imperial e republicano. Dialogando com alguns especialistas da história da imigração e colonização do Brasil no século XIX, procuramos frisar que o processo migratório é produtor de formas geográficas que se cristalizam por meio de normas e/ou regulações jurídicas, sociais e culturais do passado. Tais processos relacionam-se às relações sociais, de propriedade e apropriação territorial, além dos requisitos vinculados à produção e distribuição de "objetos geográficos" ${ }^{3}$.

A tentativa de nos manter "vigilantes epistemologicamente" dos conteúdos produzidos a partir da leitura de diversas fontes não exime a possibilidade de enfrentarmos alguns problemas metodológicos na interpretação de nosso objeto. Nesse sentido, consideramos que as eventuais lacunas deste artigo são encaradas como possibilidades de entender que todo conhecimento pretérito é sempre uma verdade possível de interpretação4 .

Ciente de tais desafios, sabemos dos riscos em trabalhar com discursos proferidos por distintos grupos políticos, e, por isso, ao lermos as fontes, as vislumbramos como "artefatos culturais" e "instrumentos de poder". Compreendemos que é fundamental conhecer quem, como e em que momento foram produzidos os documentos; como os relatórios, ofícios, pronunciamentos políticos, mensagens e demais peças administrativas e de propaganda. Assim, para desvendar a "verdade" destas fontes foram requeridos os seguintes movimentos: a interpretação do contexto no qual tais documentos foram produzidos, a revisão historiográfica do tema e a análise do conteúdo das peças utilizadas. Assumimos como pressuposto que ao ler um documento e as instituições que os resguardam devemos sempre indagar as intencionalidades contidas nesses objetos/instituições.

\footnotetext{
2 Vasconcelos (2009).

${ }^{3}$ Inspiramos - nos em conceitos de espaço e território de Milton Santos, discutidos ao longo de sua trajetória acadêmica.

${ }^{4}$ LOWENTHAL, David. Como conhecemos o passado. Projeto História. São Paulo, v.17, nov. 1998, p.71.

$\begin{array}{lllll}\text { Caminhos de Geografia } \quad \text { Uberlândia-MG } & \text { v. 22, n. } 81 \quad \text { jun./2021 } & \text { p. 127-149 Página } 128\end{array}$
}


Partindo dessas perspectivas teóricas e metodológicas, os aspectos mobilizados para compreender as organizações espaciais pretéritas serão dirigidos à análise das querelas que envolvem a política administrativa do Estado e os processos de difusão espacial das inovações, atreladas direta e indiretamente à política migratória. Ao elegermos Rio de Janeiro e Minas Gerais como espaços privilegiados para a análise do processo imigratório, consideramos que os movimentos de ideias, mercadorias e população articulados aos mercados globais de mão de obra redefinem, em diferentes contextos, o papel de comando de algumas áreas e explicam as diversas nuances das disputas regionais no período republicano ${ }^{5}$.

O estabelecimento de imigrantes, considerados símbolos do progresso no alvorecer da República, recrudesce, a um só tempo, os debates sobre modernização e os conflitos regionais. O fenômeno migratório torna-se, assim, importante variável para compreender as estruturas espaciais em diferentes níveis e escalas geográficas, constituindo-se, portanto, em um dos mais relevantes processos de desbravamento de fronteiras e de formação de uma região. As propostas de imigração estrangeira abrem-nos possibilidades para desvendar singularidades do conflituoso processo de formação de uma identidade territorial; movimento atrelado à organização de um espaço e de criação de regiões. Trata-se de um estratagema geopolítico, na medida em que implica o manejo de questões territoriais a partir das abordagens, perspectivas e interesses dos Estados e sociedades. Diante desse panorama, em um momento de crise da lavoura cafeeira e ascensão política de São Paulo, nossa intenção é demonstrar como a questão da imigração no final do século XIX e começo do XX foi acionada como importante trunfo político nos estados do Rio de Janeiro e Minas Gerais. Integrada às disputas por recursos e possibilidades de conquista de novas frentes econômicas, as propostas de imigração transformar-se-iam em um dos principais epicentros dessas lutas por poder e território.

Sobre o argumento de articular os diferentes espaços e modernizar o território, endossava-se nos projetos imigratórios a necessidade de implantar ferrovias, estradas, correios, telégrafos, casas e hospedarias; movimento que contribuía para reforçar o papel polarizador de algumas cidades e de suas regiões de influência. Tais infraestruturas, consideradas imprescindíveis à vinda de imigrantes, desencadeavam significativos efeitos espaciais. Atrelada à capacidade dos entes federativos de gerar e distribuir fluxos e de integrá-los ou excluí-los dos circuitos econômicos e políticos, a imigração contribuiu para o nascimento e multiplicação das redes política, viária, urbana, comercial, produtiva, etc. É, também, pela via imigratória que projetos civilizacionais de corte eugênico encontrariam terreno fértil para por em prática o desejo de algumas elites em tornar seus estados polos da modernidade aos moldes da Europa ${ }^{6}$. Em uma sociedade em que teorias cientificistas como o determinismo e o evolucionismo teriam grande repercussão, o discurso imigratório, sem dúvida, trouxe no seu bojo mudanças de caráter cultural, que ainda prevalecem na história e memória de muitas cidades e regiões.

Partindo da ideia de que as questões imanentes à imigração instauraram uma verdadeira batalha em torno do "corpo" do imigrante, em um primeiro momento problematizamos como os discursos alusivos às potencialidades e limites do território mineiro e fluminense forjaram jogos de representações espaciais via discurso regional e local. Em seguida, comparamos as principais

\footnotetext{
${ }^{5} \mathrm{~A}$ introdução do navio a vapor, do telégrafo e da ferrovia, associada à demanda por trabalhadores, aproximou as fronteiras atlânticas. Tal processo decorrente dos avanços técnico-científicos gerou efeitos em diferentes escalas no conjunto de atividades econômicas que se desenvolveram a partir na segunda metade do século XIX. O transporte, circulação e distribuição massiva de mercadorias e emigrantes europeus para o Novo Mundo é um desses efeitos que marcaram a história do capitalismo na era industrial.

${ }^{6}$ No entanto, embora o embranquecimento da população, fundamentado nas teorias racialistas seja evidentemente vinculado aos setores capitalistas mais estruturados e relacionado ao desenvolvimento de uma ética de trabalho, havia também questionamentos do emergente movimento negro. Este difundia, através de alguns jornais e associações, críticas contundentes à imigração estrangeira e a decorrente desvalorização da mão de obra nacional (PINTO, 2013).
} 
estratégias territoriais empregadas pelas elites políticas que comandavam estes entes federativos para superar a propalada crise da lavoura.

\section{Como receber os imigrantes estrangeiros?}

Associado ao contexto internacional e ao maior endividamento do Império, a partir de meados dos anos 1860 , a crise no setor agrícola se ampliou devido à diminuição do preço do café e às dificuldades de obtenção de mão de obra escravizada, como demonstram os vários relatos das autoridades ministeriais e provinciais. Nessa medida, os problemas enfrentados nas colônias governamentais, instaladas entre os anos de 1840 e 1850, expressavam as disputas em torno dos diferentes projetos de modernização e, também, as divergências em relação ao controle das terras e à política de povoamento nos sertões.

A organização do Congresso Agrícola em 1878 é um marco importante em relação a estas questões, pois expressa, a partir dos projetos apresentados durante a década de 1870, as diferentes propostas dos entes federativos. Com o intuito de discutir a salvação da lavoura, e contando com a participação dos principais fazendeiros do Rio de Janeiro, São Paulo e Minas Gerais, este fórum foi marcado por acirrados debates ao redor da temática imigratória, pontuando-se três principais problemas: i.) a escassez de mão de obra; ii.) as dificuldades de fixação dos imigrantes estrangeiros nas grandes fazendas; iii.) a disputa regional por recursos para atrair mão-de-obra.

No que se refere às queixas apresentadas pelas lideranças fluminenses, destacam-se a crise da agricultura decorrente do desgaste dos cafezais; a concorrência interna (principalmente a dos plantadores de São Paulo), a falta de braços escravizados e os problemas de fixação dos imigrantes europeus nas fazendas. Para atender parte dessas reivindicações, uma das principais decisões foi a promulgação de uma lei de locação de serviços que visava atrair também os "braços nacionais" para as colônias de parceria. É nessa medida que, em atenção aos interesses dos grandes fazendeiros, com destaque aos de São Paulo, o projeto de imigração espontânea ganha maior força na pauta política. A filiação a esse sistema, como propugnavam seus defensores, objetivava maior liberdade de negociação às províncias e melhor desempenho nos processos de recrutamento, transporte e distribuição dos imigrantes no território brasileiro.

A promulgação da Lei Sinimbu (Decreto № 2.820, de 22/03/1879) emerge como decorrência desses embates entre o poder central e as lideranças regionais. Além dessa Lei, de uma maneira geral, o conjunto legislativo ${ }^{7}$ facilitou a entrada de trabalhadores estrangeiros no país e ampliou a autonomia dos estados ao minimizar a participação da União nas subvenções financeiras voltadas à imigração ${ }^{8}$. No entanto, mesmo participando de forma limitada na matéria, em muitos casos é a União que se responsabiliza pelo transporte dos imigrantes aos estados. Nesse contexto, em virtude desenvolvimento da indústria cafeeira paulista, a nova legislação imigratória acaba beneficiando as elites paulistas (PETRONE, 1978).

Nos anos 1880, diversos fatores contribuíram para a elevação exponencial do fluxo de emigrantes espontâneos para o Brasil: a crise econômica na Europa, o barateamento do transporte marítimo, o maior controle dos Estados-Nações em relação aos abusos cometidos pelos agenciadores aos imigrantes, e, finalmente, uma maior organização das empresas responsáveis pelo transporte e abrigo

\footnotetext{
7 Destacamos a promulgação de quatro instrumentos: a) o Decreto 528, de 28 de junho de 1890) que colocava para o governo a tarefa de reembolsar "total ou parcialmente" o valor das passagens de navio da Europa; b) a Constituição de 1891, que transferia aos estados o controle das terras públicas entre outras medidas; c) a Lei de 1894, que tornou a imigração e à colonização competências exclusivas dos estados, sendo somente de responsabilidade da União o controle dos portos e das fronteiras e a primeira triagem dos imigrantes; d) as medidas adotadas em 1896 que retiraram o apoio financeiro do governo, via subvenções, ligadas à imigração (DIEGUES, 1964).

${ }^{8}$ Em 1906, conforme mencionado pela historiografia sobre imigração, a União modifica totalmente a sua forma de participação na política imigratória. 
dos estrangeiros.

Um importante aspecto que explica o aumento do fluxo migratório é o desenvolvimento de uma política sanitária e a consequente reestruturação das hospedarias existentes. Nesse contexto, tais objetos geográficos se transformam em espaços melhor estruturados de recepção, acolhimento, controle e registro do fluxo massivo e contínuo de imigrantes ${ }^{9}$. As doenças, que fundamentariam políticas e acordos nacionais mais adequados às exigências internacionais, alimentariam imagens que associavam lugares à ocorrência de epidemias, o que contribuía para edificar "paisagens enfermas" associadas às cidades e regiões. A lógica do controle das doenças iria engendrar dispositivos jurídicos de teor racial que restringiriam a entrada de imigrantes em função da instalação de hospitais, hospedarias, lazaretos, depósitos e armazéns, seja nas cidades, espaços rurais e/ou em ilhas (quarentena). Portanto, um componente que iria atiçar a disputa por imigrantes nas cidades e regiões se vincularia a capacidade das lideranças em esculpir uma "paisagem sã".

Nessa esteira, algumas instituições de caráter comercial e científico são criadas e foram mobilizadas para atrair os imigrantes para os estados, como foi o caso da Sociedade Central de Imigração-RJ (18831891), da Sociedade Promotora de Imigração em Minas Gerais (1887) e a da Sociedade Promotora de Imigração em São Paulo (1886-1895), etc. Misturando "negócios públicos com coisa privada", tais entidades objetivavam divulgar as potencialidades econômicas das localidades e regiões, incentivar o tráfego e a instalação e distribuição dos imigrantes ${ }^{10}$.

\section{São Paulo deve nos servir de exemplo:}

S. Paulo deve nos servir de exemplo.

Aquelle estado, so teve uma politica ousada, permita-se-me a espressão, nessa questão de immigração e colonisação, está hoje tirando magnificios resultados dessa politica.

É assim que S. Paulo é mais conhecido, por exemplo na Italia, do que muitos estados da Europa.

Lá o immigrante diz com toda a franquesa - eu não vou para o Brazil; vou para S. Paulo.

Nós temos uma hospedaria de immigrantes que o governo federal tomou a si, e entretanto, o que vemos é que os immigrantes, chegando ali, desde que entram em Minas, ficam aborrecidos, e logo fasem gréve para se retirarem o mais depressa para São Paulo (O ESTADO DE MINAS, 20. nov. 1891, p.1).

A frase que descortina o trecho acima - "São Paulo deve nos servir de exemplo" - talvez seja uma das que melhor condense a admiração dos mineiros em relação à política imigratória paulista. Essa vontade de se espelhar em São Paulo tornava-se ainda mais vívida quando os políticos denunciavam o estágio de letargia que pairaria sobre as Gerais. Dizia-se que ao passo que São Paulo se engrandecia e o Rio de Janeiro seguia conservando "sua autonomia de cabeça do Imperio", Minas Gerais, "esse colosso respeitavel", permanecia "inerte, abatida e desprestigiada, não obstante a sua numerosa população, as riquezas mineraes que encerra em seu seio, a uberdade de seus terrenos e a fertilidade de seus campos" (A VERDADE, 26.ago.1886. p.1). Argumentava-se que a abolição da escravatura, somada à administração ineficaz do Estado, concorria para desorganizar o trabalho, acometendo, assim, a lavoura cafeeira. Esse alegado marasmo era considerado inadmissível diante das potencialidades mineiras que, segundo relatos, gabaritariam Minas Gerais não só a alcançar o progresso dos vizinhos paulistas como, também, ultrapassá-lo. Para isso recomendava-se que os governantes não poupassem

${ }^{9}$ A esse respeito ver Chysostomo e Vidal (2014).

10 Destacamos a do Rio de Janeiro instituída em 1883, e a de Minas Gerais em 1889. 

Higor Mozart Geraldo Santos

esforços e, assim como os paulistas, investissem na vinda de imigrantes estrangeiros. Não por acaso, a Sociedade de Geographia Econômica de Minas Geraes assinalava a necessidade de "mostrar ao mundo" os predicados mineiros que permaneciam desconhecidos:

Até hoje, forçoso é confessal-o, Minas permaneceu desconhecida do resto do mundo e até quasi que ignorada mesmo pelas outras antigas provincias suas irmãs. Na Europa bem poucos a conhecem e ninguem sabe exactamente quão valiosos os elementos que possuimos para nos tornarmos fortes e respeitados (A ORDEM, 18. jan. 1890, p.1).

Por conta de diagnosticada inércia, havia uma série de esforços conclamando medidas para imprimir um novo ritmo às Gerais, o que incluía narrar, por todos os lados, em alto e bom tom, as qualidades do patrimônio geográfico mineiro

\begin{abstract}
Sem receios de contestação, digamos bem alto que Minas - com territorio maior que grandes potencias da Europa, com recursos superiores aos de Estados que sustentão exercitos, armadas e governos aparatosos e custosos; com mais de tres milhões de habitantes, offerece a todos que quizerem trabalhar os meios de attingirem, mais facilmente que em qualquer outra parte, o fim que todos nós devemos ter em vista: crear filhos que vivão de um trabalho livre e independente. Não nos amendrontemos com a grandeza do commettimento, nem com as difficuldades a vencer. Unamo-nos tenhamos fé e venceremos (A ORDEM, 18. jan. 1890, p.1, grifos nossos).
\end{abstract}

O retrato de uma Minas Gerais exaltada pela grandiosidade de seu território era confrontado à ideia de estagnação, como pode ser visualizado nas abundantes menções sobre a timidez das estratégias voltadas à atração e acolhimento de imigrantes. Exemplo disso é ilustrado em 1894 quando o senador Camillo de Britto ${ }^{11}$ mencionava que apenas 1.580 imigrantes tinham sido introduzidos nas Gerais, ao passo que nas terras paulistas fixaram-se 17.000. Esses índices ficavam ainda mais alarmantes no momento em que Costa Sena ${ }^{12}$, também senador, sublinhava a diferença significativa de extensão territorial entre os estados. Diante da baixa densidade demográfica, o senador argumentava que a fixação do estrangeiro somente ocorreria quando ele se tornasse proprietário e, por esse motivo, Minas Gerais poderia obter alguma vantagem diante de seu vasto território. Dizia o político que em contraposição às ofertas paulistas, o grande trunfo mineiro seria a incomensurável fartura de sua natureza: "Um pedaço de terra e alguns animaes são para elle atractivo muito mais poderoso que os salarios elevados" (MINAS GERAES, 5. jun. 1895, p.6). De sua ótica, a colonização era importante, no entanto constituía-se uma medida mais lenta, o que contrariaria a urgência reclamada pela lavoura. Por isso, ele julgava que o governo não poderia esperar a saturação de imigrantes em São Paulo e seu transbordamento para Minas Gerais:

A colonização [...] é um remédio lento, e a lavoura reclama serios e urgentes auxilios, sem os quaes não poderá mais luctar com os embaraços que contra ella surgem.

O Estado de S. Paulo é bastante vasto. Si formos esperar que elle se sature de immigração para que de lá venha ella para cá, ou para que, sem sua concurrencia possamos fazer o serviço em melhores condições, a lavoura, terá tempo de se aniquilar algumas dezenas de vezes, e o Estado de amontar deficit sobre déficit (MINAS GERAES, 5. jun. 1895, p.6).

\footnotetext{
${ }^{11}$ Camillo Augusto Maria de Brito foi político, promotor, magistrado e professor. Durante a Monarquia pertenceu ao Partido Liberal e na República ao Partido Republicano Mineiro. Elegeu-se para a Constituinte Estadual e para a $1^{\text {a }}$ Legislatura do Senado (1891-1895), ao qual foi reconduzido da $2^{\underline{a}}$ a $9^{\underline{a}}$ Legislatura (1895-1926) (MONTEIRO, 1994).

12 Joaquim Cândido da Costa Sena, nascido em Conceição do Serro, Minas Gerais, em 13 de agosto de 1852. Formado em Engenharia de Minas de Ouro Preto (1880), tendo sido também diretor dessa mesma escola. Entre outras ocupações, participou da Constituinte Mineira e do Senado de Minas. Após a morte de Silviano Brandão, chegou a Presidência do Estado de Minas (ESCOLA DE MINAS DE OURO PRETO).
} 
Ao esboçarem estratégias para tornar Minas Gerais um centro de imigração florescente, os políticos mineiros adotam uma série de medidas para fixar o estrangeiro, a exemplo das hospedarias - que, a essa altura, se convertem em um dos mais importantes ingredientes da política de imigração. A importância desse dispositivo pode ser visualizada nos pronunciamentos e ações de alguns de seus políticos: "Acudindo o appelo administracao publica, diversas municipalidades começaram a tomar medidas para a creação de hospedarias e ja tem sido definitivamente auctorizada a fundação de hospedarias municipaes em S. João Nepomunceno e Rio Novo" (REVISTA INDUSTRIAL DE MINAS GERAES, 15.fev.1895, p.51).

Como sugerem as informações da Figura 1, ao findar do XIX e começo do XX a fundação de núcleos, de estruturas de acolhimento (como as hospedarias) e o oferecimento de terras devolutas pelas lideranças locais para instalação de núcleos, revelam estratégias políticas, de caráter intra e interregionais, de atração de imigrantes. Nas disputas circunscritas às fronteiras administrativas do estado, prevalecia a ideia de que as hospedarias e os núcleos de colonização seriam grandes trunfos para as cidades que disputavam imigrantes e demais infraestruturas; daí a sua concentração nas regiões mais florescentes do ponto de vista econômico. A definição de distritos de imigração, que contemplava apenas algumas cidades, serve para exemplificar o caráter estratégico dessa política e, também, os liames de uma disputa por recursos que se acirrou na região. É possível notar, pelas informações descritas na figura adiante, que praticamente toda a região nordeste do estado não integra nenhum distrito imigratório. Nessa medida, salta aos olhos como as regiões estão equipadas de maneira desigual em relação aos dispositivos ligados à imigração. Vale atentar que além das disputas internas, o principal interesse das elites mineiras era reposicionar Minas Gerais nas estatísticas da imigração brasileira, superando o descompasso em relação a São Paulo e, ainda, a importância política do Rio de Janeiro.

Figura 1 - Mapa das colônias, hospedarias e distritos de imigração em Minas gerais (1888-1930).

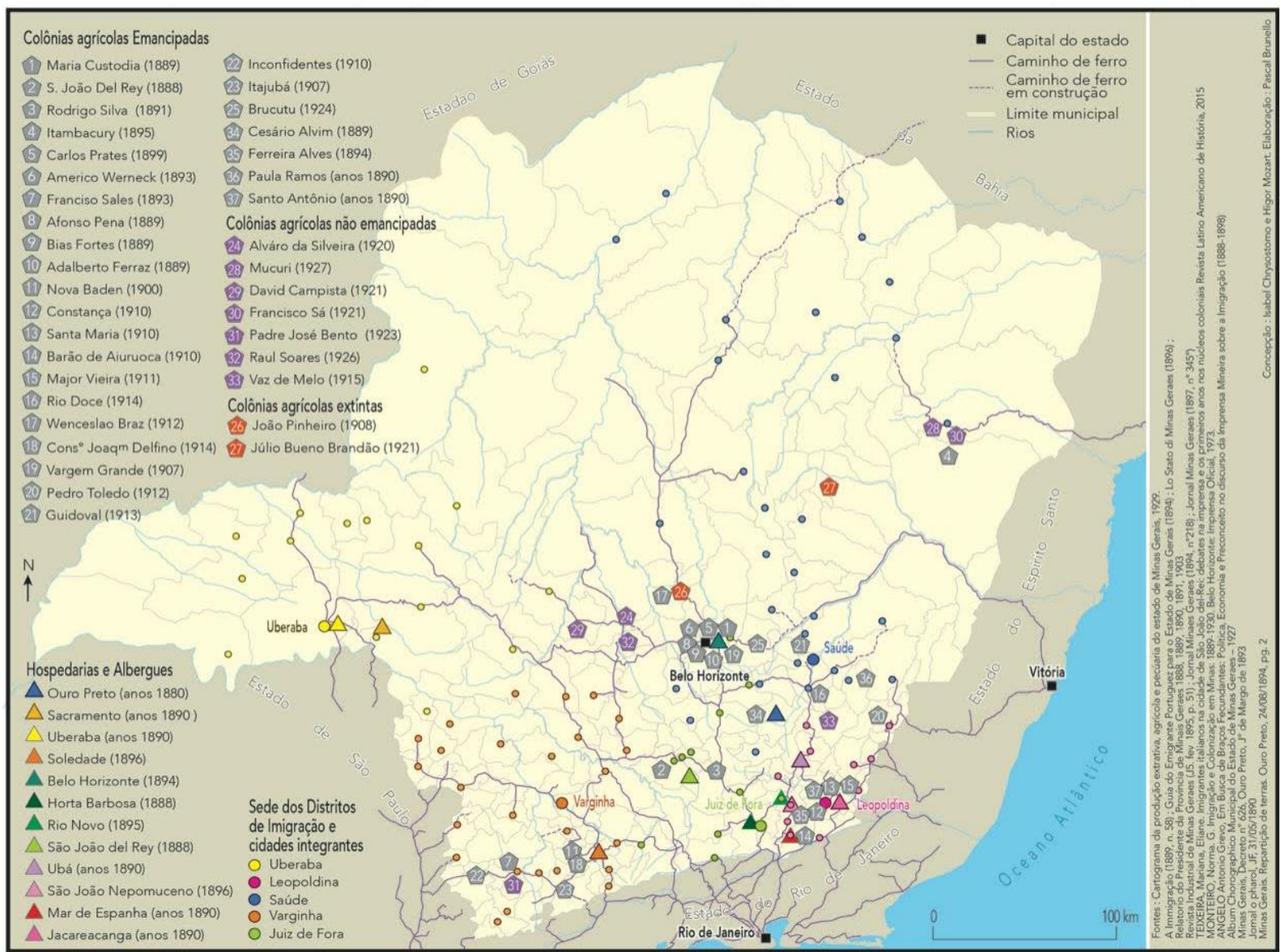



Higor Mozart Geraldo Santos

Tendo em tela esse cenário, é mais especificamente na virada do século XIX para o XX que os mineiros, finalmente, se atentam com maior afinco para o dito atraso das Gerais. Nesse momento, os projetos de desenvolvimento regional ganham mais vulto e, passam a alimentar ações destinadas a suprir os alegados problemas de povoamento, falta de articulação do território e improdutividade da lavoura. Destacamos, nesse sentido, a constituição de um importante fórum de discussão realizado graças à iniciativa encampada pelas elites mineiras - o I Congresso Agrícola, Comercial e Industrial de Minas Gerais (I CAIC), realizado em 1903, na recém-fundada Belo Horizonte ${ }^{13}$.

Apesar dos quase quatro meses de estudo neste fórum constituir-se em um marco da política econômica mineira, as decisões tomadas, apresentaram grau de inovação extremamente diminuto, já que em termos práticos, a ousadia cedeu lugar ao esforço de sistematizar o que já vinha sendo realizado de forma tímida ${ }^{14}$. Todavia, tal Congresso - frisa-se, permeado por interesses múltiplos vinculados, sobretudo, às demandas particulares das elites regionais - pode ser enxergado como "a primeira experiência vertical de sistematização do problema econômico em Minas por parte do poder público, intentando organizá-lo por meio de diagnose e intervenção" (BARBOSA, 2012, p.15).

A realização desse Congresso é mais uma das medidas que revela os esforços dos governantes de Minas Gerais em superar o letargo, se valendo de discursos geográficos que ressaltavam a qualidade e quantidade das terras disponíveis. A tônica desse relevante fórum sempre explorava a incompatibilidade entre o estágio de desenvolvimento e as virtualidades do território, produzindo, de maneira hábil, uma ambiência favorável à imigração. Nesse sentido, propostas como investimento na qualificação dos trabalhadores nacionais, disseminação do uso de maquinário agrícola, investimento em policultura, entre ações outras, objetivavam tornar a economia mineira mais robusta e dinâmica.

\section{Como trazer imigrantes para o Rio de Janeiro?}

A solução do problema imigratório no nosso Estado é difícil. Tudo conspira contra nós. A própria denominação do nosso Estado, o seu título distintivo, é um embaraço. Na Europa - o Rio de Janeiro e a febre amarela, são ideias associadas $^{15}$.

A preocupação enunciada nessa mensagem dá o tom aos dos principais desafios enfrentados pelos políticos fluminenses para atrair imigrantes na recente República, quais sejam: a crise da lavoura fluminense a partir dos anos $1880^{16}$, as diversas epidemias que assolavam a capital, com desdobramentos em importantes regiões produtoras; a imagem do estado no exterior, e as manifestações de protesto pela autonomia do Rio de Janeiro ${ }^{17}$. A despeito de décadas com diagnósticos e prognósticos semelhantes sobre a temática imigratória, as propostas de povoamento do território foram esculpidas pelas lideranças políticas em dois momentos. $O$ primeiro compreende 0 período de nascimento e consolidação do Partido Republicano Federal ${ }^{18}$, que colocou em evidência o

13 O Congresso foi realizado na presidência de Francisco Salles e liderado por João Pinheiro, ex-presidente do estado. Este voltaria ocupar a presidência do estado em 1906.

${ }^{14}$ Com efeito, houve um total de 119 recomendações distribuídas a partir dos seguintes temas: Mineração e Águas Minerais (13 itens); Indústria em Geral (10 itens); Agricultura (9 itens); Comércio (20 itens); Pecuária (22 itens); Tecelagem (6 itens); Viação Férrea e Tarifas (9 itens); Estradas de Rodagem (5 itens); Café (5 itens); Curtumes (4 itens); Viti e Vinicultura (5 itens); Bancos (11 itens).

${ }^{15}$ Mensagem 1902 (Rio de Janeiro). Disponível em: <brazil.crl.edu/bsd/bsd/u871/000049 p.25-26>.

16 Lobo (1996) sinaliza dois efeitos decorrentes da decadência da lavoura cafeeira: a) a partir de 1883 o crescimento da migração do interior do estado para a Capital; b) a partir de 1886 seguido até 1892 um aumento significativo de imigrantes que aportaram na Corte.

${ }^{17}$ A crise econômica era decorrente da reforma financeira, conhecida como encilhamento, realizada pelo ministro Rui Barbosa em 1891. Seus desdobramentos beneficiaram, sobretudo, o setor cafeeiro paulista e mineiro.

${ }^{18}$ Conforme discute, Costa (2006) houve no Rio de Janeiro algumas tentativas para se criar tal Partido, no entanto 
poder das elites paulistas e a fragilidade da economia cafeeira no Rio de Janeiro ${ }^{19}$. Sublinhamos, neste contexto, a fundação da Companhia Metropolitana de Colonização em 1893, cuja história teve início no ano anterior quando o governo central a incumbiu de introduzir um milhão de imigrantes da Europa e das possessões portuguesas e espanholas, em um prazo de 10 anos. A partir desta tentativa que se demonstrou fracassada, ressaltamos a promulgação de duas leis no findar de 1895 que redefinem o raio de ação do governo fluminense ${ }^{20}$. Uma delas, de escopo regional, estabeleceu três zonas agrícolas em centros políticos de grande envergadura, que, não por acaso, sediavam as cidades em disputa pelo título de capital: a zona cafeeira, a açucareira de Campos e a zona constituída pelas terras frias que se estendiam de Petrópolis a Teresópolis ${ }^{21}$ (Ver Figura 2). A segunda lei, de âmbito nacional, transferia, após a conturbada rescisão do contrato celebrado com a Companhia Metropolitana, a responsabilidade do recrutamento de imigrantes aos estados federados.

Portanto, como reação à perda de prestígio da elite fluminense desfrutadas nas primeiras décadas do Império, foram esboçadas as seguintes proposições: a) criação das zonas agrícolas; b) estações agronômicas; c) subsídios à imigração (a partir de estímulos concedidos à iniciativa privada para organizar Centros de Povoamento); d) criação de núcleos coloniais ${ }^{22}$; e) distribuição de adubos químicos; f) adoção de medidas paralelas e complementares, como o saneamento da baixada; g) instalação de hospedarias estaduais em áreas estratégicas - a exemplo das construídas em Niterói e Friburgo, as quais seriam reunidas às de Cabiúnas em Macaé, e a que o governo estabeleceu na fazenda Boa Vista, na cidade de Paraíba do Sul ${ }^{23}$ (Ver Figura 2).

O segundo momento corresponderia a um tipo de reação fluminense à hegemonia de São Paulo, que se estruturou em função de facções de lideranças fluminenses organizadas no Partido Republicano do Rio de Janeiro ${ }^{24}$. As propostas expressas pelo líder dessa corrente Alberto Torres, durante sua gestão (1898-1900) ${ }^{25}$, centravam-se em três principais estratégias de recuperação econômica: i) política protecionista e diversificação da agricultura, visando o fortalecimento do mercado interno; ii) aproveitamento da mão-de-obra nacional; iii) difusão da pequena propriedade; iv) redução de gastos públicos visando ampliação a receita (Relatório do Presidente do Estado, 1898). Além disso, compunha

sem êxito. O mesmo autor assinala que a opção pela República era pensada a partir de duas vias - uma revolucionária, protagonizada por Silva Jardim e a outra evolucionista, defendida por Quintino Bocaiuva; fato que não ocorria no movimento republicano de São Paulo. Uma outra questão que passou a ser central para a constituição desse partido foi a sua adesão à abolição da escravatura, opção ambígua já que de um lado ela era defensora da manutenção da grande propriedade, atraindo em plano nacional um número expressivo de grandes fazendeiros, que eram ex-escravistas que se consideravam injustiçados com a Monarquia.

${ }^{19}$ Destacamos que tal processo foi marcado por sérios conflitos políticos que levaram, inclusive, a atos de violência e fechamento do Congresso do Estado do Rio de Janeiro em 1891. Esse imbróglio teve impacto nas relações políticas com Portugal a partir de 1893, o que levou à interrupção do fluxo imigratório até meados de 1895, momento em que as negociações foram reatadas e assistiu, nos dois anos seguintes, um incremento do fluxo de portugueses (LOBO, 1996).

${ }^{20}$ Referimo-nos à lei n.260 de 27 dezembro de 1895 e à Lei n. 360, de 30 de dezembro de 1895

${ }^{21}$ Lei n.260 de 2771271895.

$22 \mathrm{Na}$ Mensagem do Presidente (1895) ele mencionava tal demanda e colocava a necessidade de se votar uma lei que gerasse recursos para compra de terrenos, nos quais pudessem ser estabelecidos núcleos coloniais organizados pelo governo: "Seu povoamento constituirá centros de atração para a vinda de imigrantes, parecendome este o único meio de obter-se corrente immigratoria apta para o desenvolvimento da nossa agricultura e das industrias que lhe são conexas" (MENSAGEM DO PRESIDENTE DO ESTADO DO RIO DE JANEIRO, 1895, p.22). ${ }^{23}$ Além dessas hospedarias, registra-se a existência de um Trapiche da rua da Saúde, de propriedade privada. Tratava-se de um Depósito provisório utilizado pela Inspetoria de Imigração como hospedaria para abrigar as levas de cearenses chegados ao Rio de Janeiro em decorrência da seca, uma vez que não havia espaço na llha das Flores (Relatório do Presidente da Província, 1888, p. 19). Em 1901, as hospedarias de Cabiúnas e Boa Vista, criadas em 1896, foram extintas, subsistindo a da llha do Carvalho (Mensagem do Presidente do Estado do Rio de Janeiro, 1901)

${ }^{24}$ Tal partido originou-se da dissidência do Partido Republicano Fluminense. Esta etapa, segundo Ferreira (1989), finaliza uma longa etapa de domínio político do paulinismo.

${ }^{25}$ Republicano histórico e governador do Rio de Janeiro no período de 1898 a 1900, se destacou como liderança ao redefinir as forças políticas do Rio de Janeiro junto ao partido republicano federal, criando, ao final, o PRRJ Partido Republicano do Rio de Janeiro. 

Higor Mozart Geraldo Santos

sua fórmula para salvar a economia fluminense, a continuidade dos estudos da Comissão de Saneamento, o que indicava a possibilidade de expansão do setor agrícola em direção à Baixada.

Considerando de grande utilidade educar os lavradores, Torres mantinha a proposta de criar sociedades agrícolas e incentivar as exposições dos agricultores, assim como estimular o ensino prático de agricultura. Recomendava, portanto, a criação do Conselho Geral de Agricultura com o propósito de animar o espírito de associação; medida regulamentada pelo Decreto 470 de 27 de maio de 1898. No entanto, ele ponderava a eficácia de algumas medidas ligadas à imigração devido às elevadas despesas que esse setor requeria, argumentando os problemas da evasão dos imigrantes seja para o campo, cidades ou para o estado de São Paulo. Para resolver tal imbróglio, propunha que parte dos recursos destinados a essa demanda ficasse a cargo dos lavradores, e que o Estado auxiliasse apenas o custeio das passagens. Suas ideias não eram diferentes quanto à fixação de colonos nos núcleos, uma vez que julgava ser mais adequado delegar à iniciativa privada a sua fundação e manutenção, a partir da concessão de favores indiretos aos interessados.

O seu sucessor, Quintino Bocaiuva, em 1901 continuava a defender a criação de colônias agrícolas, afirmando que só o povoamento poderia salvar o improdutivo território fluminense e resolver os problemas econômicos da lavoura cuja transformação estava sendo reclamada pelos péssimos resultados da monocultura. Para Bocaiuva, o povoamento "base do [...] progresso agrícola", possibilitaria a "lenta e suave evolução natural do território". Nesse aspecto, a imigração "fonte principal e quase exclusiva da riqueza publica e particular", levaria as autoridades a pensarem "no erro funesto de facilitar braços aos lavradores" no lugar de radicar o imigrante ao solo "vinculando-o, pelo interesse próprio, no arroteamento e na cultura do torrão que ele adquira ou venha a adquirir como propriedade sua"26.

Ao assinalar que nenhum outro estado da federação reunia condições mais adequadas para o progresso da lavoura em função da posição geográfica, abundância de meios de transporte e proximidade do maior mercado de consumo e de exportação, Bocaiuva anunciava a assinatura, ainda sem aprovação, de contratos para estabelecimento de núcleos coloniais e a instalação de uma fazenda modelo (Mensagem Enviada a Assembleia Legislativa em setembro pelo presidente do estado Alberto de Seixos Martins Torres, sessão 15 de setembro de 1901, p. 18 e 19).

A ascensão em 1903 de Nilo Peçanha ao poder estadual - apoiado, inclusive, por parte de lideranças mineiras - consolidava o projeto em curso de promover o crescimento da economia fluminense com o interesse de torná-la uma nova potência regional. Na base de seu programa de revitalização econômica estavam medidas como: redução de impostos de exportação, o que beneficiava produtores fluminenses; incentivo à policultura; acesso mais fácil aos instrumentos agrícolas (inclusive com o fornecimento gratuito de mudas e sementes); criação de estações experimentais, centros agronômicos e estabelecimentos agrícolas.

Em discurso propalado à Assembleia, o chefe do executivo anunciava que a colonização entraria em uma nova fase devido ao maior apoio da União ${ }^{27}$. Nesse sentido, apresentava um Plano de Colonização que, segundo suas palavras, permitiria a fixação do colono ao solo. As bases centrais deste plano consistiam na medição, demarcação e alocação de infraestrutura necessária a cultura intensiva. Nesse contexto, Nilo Peçanha anunciava a criação do primeiro núcleo de colonização em Teresópolis; escolhido graças à amenidade climática, fertilidade do solo e altitude. Ao colocar tais fatores como essenciais para o desenvolvimento da política de imigração, o político relatava preferência por estabelecer os primeiros núcleos coloniais em planaltos situados nos municípios de São Francisco de Paula e Santa Maria Magdalena por apresentarem terras férteis, salubres e banhada por extensa rede

${ }^{26}$ Mensagem Enviada a Assembleia Legislativa em setembro pelo presidente do estado Alberto de Seixos Martins Torres, sessão 15 de setembro de 1901, p. 18.

${ }^{27}$ Ele citava os benefícios que foram promulgados União a partir do Decreto de 6.455, de 19/04/1907. 
fluvial.

Os planos de Nilo Peçanha são, de certa maneira, acompanhados de seus sucessores do mesmo partido, a exemplo de Alfredo Becker (1906-1910), que, em observância à adaptabilidade climática dos japoneses às áreas quentes, propôs tanto a instalação de uma colônia em Macaé28 como a criação de outros núcleos em áreas devolutas nos demais municípios ${ }^{29}$. A despeito de sua reclamação em relação à inexistência de uma lei de colonização que facilitasse as operações no executivo, tal plano é concluído com a celebração, em 1908, do contrato com a Companhia de Emigração Imperial do Japão, que estipulava as bases para a introdução de imigrantes japoneses em Macaé ${ }^{30}$. Nesse contexto, noticiavase a aquisiçăo de uma fazenda em Itatiaia, localizada no município de Resende, que foi adquirida com a finalidade de instalar um núcleo colonial, sob administração da União.

Em um momento no qual a política fluminense começa a se fortalecer, as comissões de saneamento influenciam diretamente a política de imigração, ${ }^{31}$ tal como propugnava o chefe do executivo em sua mensagem à Assembleia: "se é certo que o saneamento dessa vasta região constitui hoje maior problema econômico e administrativo (...) não é menos verdade que o povoamento dessa e de outras zonas segue-se-lhe imediatamente na ordem das suas mais palpitantes necessidades" (Mensagem do Presidente do Estado do Rio de Janeiro, 1907, p. 37).

Associadas umbilicalmente aos projetos de povoamento do território, via imigração estrangeira, é oportuno ressaltar que além do saneamento, a ideia de incrementar um plano geral de viação com a finalidade de "dar uma organização regular ao serviço já iniciado de demarcação, discriminação e inventário dessas terras"32 era apontado como fator estratégico. As bases do referido plano estavam assentadas na articulação das vias terrestres e marítimas, ao desenvolvimento da policultura, à difusão da pequena propriedade e de técnicas agrícolas.

Mediante as proposições desse e de outros anunciados planos, é possível afirmar que as políticas de imigração estavam imbricadas àquelas vinculadas à diversificação do cardápio étnico (incorporam mãode-obra nacional e etnias outrora malquistas, a exemplo dos chins) que definiu os principais traços de um projeto de desenvolvimento territorial cujo epicentro relacionava-se às políticas de modernização do espaço fluminense.

No mapa adiante, tal aspecto pode ser apreciado tanto a partir das principais materialidades implantadas no estado em decorrência da política imigratória como na divisão do território em zonas econômicas, levando em consideração suas características ambientais e produtivas. Esse critério, mencionado diversas vezes pelas autoridades quando se pensava onde deveriam se instalar os imigrantes estrangeiros da Europa e os da Ásia, indica que argumentos geográficos de caráter evolucionista foram acionados por diversas autoridades, a exemplo de Quintino Bocaiuva, que mobilizou tal justificativa para endossar ou não, o apoio a projetos imigratórios no estado. Destacamos dois aspectos que podem ser apreciados na Figura 2: a) a instalação do maior número de núcleos

${ }^{28}$ Tal colônia foi instalada em um terreno devoluto situado na fazenda de Santo Antônio.

${ }^{29}$ Comenta que tal propriedade havia sido adquirida pelo governo estadual. Relatório do Presidente do Estado do Rio de Janeiro, 1907.

${ }^{30}$ Entre as exigências, destaca-se o fornecimento pelo Estado de terras devolutas para atender 500 famílias na fazenda Santo Antônio e, também, as passagens; questão que implicaria ao governo de solicitar a União recursos para pagar os bilhetes de passagem desses imigrantes do Japão ao porto do Rio de Janeiro. Relatório do Presidente do Estado, 1908, p. 29 e 30. A colônia mais tarde recebeu em homenagem ao presidente é batizada com seu nome.

${ }^{31}$ A primeira comissão estadual de saneamento da baixada no Rio de Janeiro foi estabelecida durante o mandato de Porciúncula em 1894, tendo funcionado até 1902. A segunda Comissão Estadual - comissão de papel - que antecedeu a Comissão Federal, notabilizou-se por recolocar o Rio de Janeiro da cena política, por meio de investimentos do governo federal (SOUTO, 2016). Cabe destacar que a grande reforma urbana colocada a cabo por Pereira Passos (1902-1906) - entre a gestão de Quintino Bocaiúva e Nilo Peçanha - foi também utilizada como argumento para justificar o dessecamento no entorno da Capital Federal (FERREIRA, op.cit).

32 Mensagem do Presidente do Estado do Rio de Janeiro, 1909, p. 38-41. 
coloniais em áreas frias, em consonância com teorias racistas que constituíam a base de um discurso geográfico; b) a instalação, por um determinado período, de estruturas de acolhimento de imigrantes, em regiões que desfrutavam de maior prestígio em decorrência da questão política e econômica.

Figura 2 - Mapa das colônias, hospedarias e zonas agrícolas no Rio de Janeiro (1870-1810).

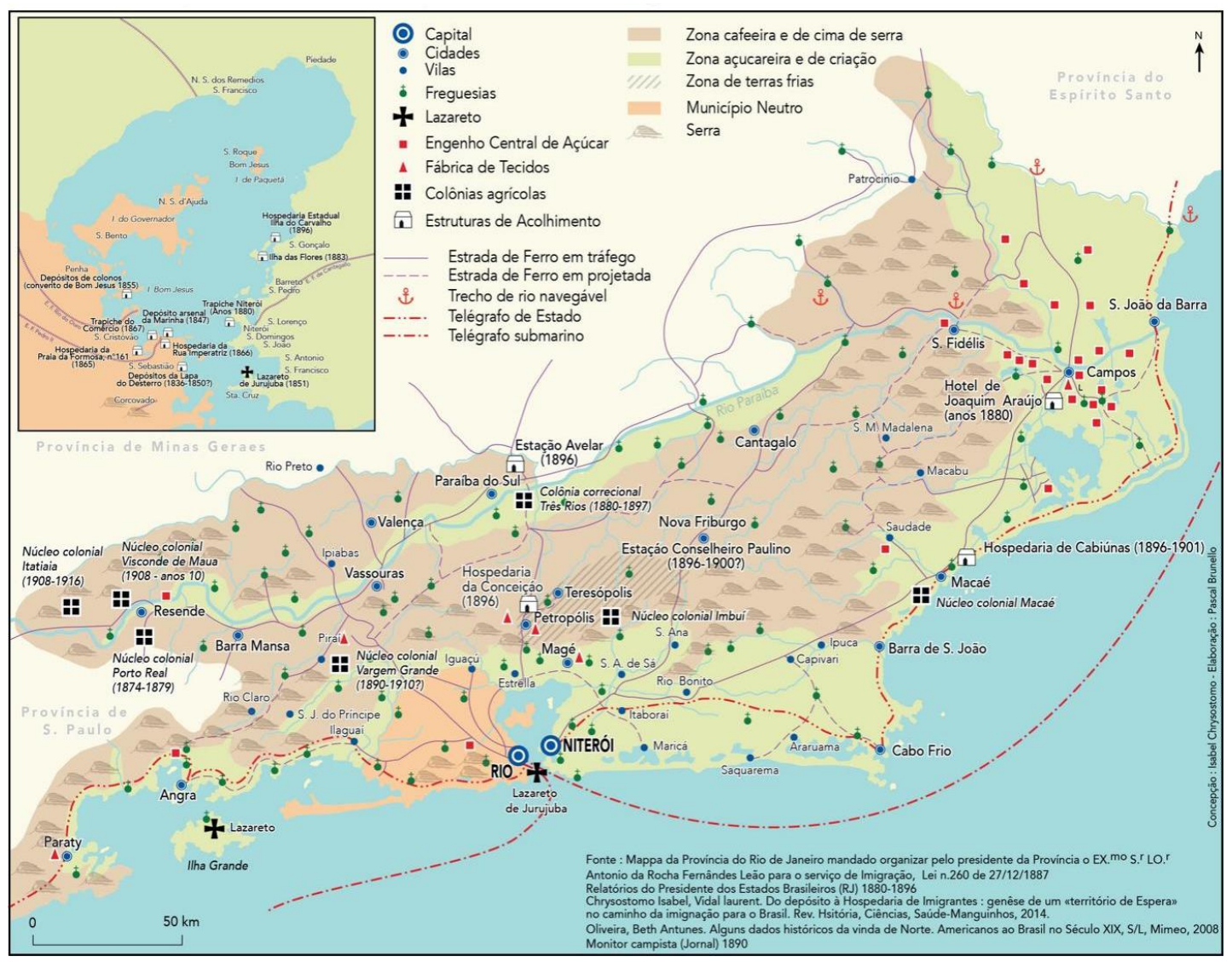

Alguns elementos de comparação para se pensar a imigração em Minas Gerais e Rio de Janeiro

A comparação de fenômenos não é tarefa fácil, pois exige, além de evidências empíricas, métodos e metodologias que permitam dialogar com os eventos e episódios de forma a não enquadrá-los rigidamente a determinados fatores explicativos. Relações de causa e efeito devem também ser problematizadas ao se comparar fenômenos sociais, de maneira a evitar constructos invariáveis e quase sempre anacrônicos no tempo e no espaço de ocorrência. Interpretar as diferenças e similitudes de um fenômeno de forma comparativa demanda, portanto, confrontá-lo às questões conceituais e conjunturais. Emerge, nessa linha, a necessidade de entender que o lugar de ocorrência de um evento deve contemplar reflexões escalares, uma vez que as relações de posição, conexão e diferença paisagística estão vinculadas às questões políticas.

O fenômeno da imigração estrangeira como fator político desencadeador de disputas regionais no começo da era republicana é o pano de fundo que sustenta o argumento central deste artigo. São nossos indicadores o contingente de imigrantes em cada estado e seus desdobramentos escalares, leia-se: maior ou menor investimento em determinadas regiões e a composição étnica da população. Os nexos da disputa entre Minas Gerais e Rio de Janeiro, tendo São Paulo como parâmetro, foram elementos essenciais para análise das variáveis, entre as quais destacam-se: o número de estruturas materiais voltadas para abrigar as levas de imigrantes estrangeiros, a disponibilidade de terras (potência do Estado nos processos de discriminação e gestão administrativa), capacidade de negociação política das elites regionais, desenvolvimento de um programa sanitário em conformidade 
com as demandas internacionais, o perfil étnico dos grupos que migraram. A partir desses indicadores e variáveis, os elementos de comparação entre Minas Gerais e Rio de Janeiro permitem entender as interconexões de ideias, projetos e ações que revelam o caráter regional assumido pelos projetos imigrantistas em um momento caracterizado pela crise política e econômica do Estado brasileiro. A seguir ilustramos alguns aspectos que denotam proximidades e distanciamentos das políticas imigratórias empreendidas por estes dois estados.

Afinado a um debate de âmbito nacional, que tinha como epicentro a questão das terras ocupadas por indígenas, são instalados entre os anos 1840 e 1850, os primeiros núcleos coloniais em Minas Gerais e no Rio de Janeiro. No território mineiro, destacamos as colônias de Mucuri (1852), Urucu (1854) e Dom Pedro II (1856). Já no caso do Rio, temos o exemplo da colônia Pedra Lisa (de curtíssima duração), Valão dos Veados e Petrópolis ${ }^{33}$ e alguns pequenos núcleos de colonização de caráter privado que adotavam o sistema de parceria ${ }^{34}$

Nesse contexto, era o Rio de Janeiro o mais importante espaço político e econômico do Brasil e, não por acaso, sociedades anônimas, companhias e investimentos privados foram realizados para atrair imigrantes com a participação de influentes empresários como Barão de Mauá. Mas esse modelo empresarial, que não era exclusividade do Rio, teve impulsão em Minas Gerais a partir da ação de dois importantes atores: a) Mariano Procópio, que juntamente com Mauá, era acionista da empresa que construiu a estrada União Indústria; b) Teófilo Otoni, político e empresário influente que traçou um ambicioso plano de modernização do Vale do Mucurii3 ${ }^{35}$ (norte e noroeste de Minas Gerais) ${ }^{36}$.

É possível dizer que o caráter regional desta disputa se deflagrou quando a questão da substituição da mão de obra por imigrantes estrangeiros se tornou uma das principais pautas políticas, convertendose em uma questão nacional. Em um contexto marcado pelas campanhas republicanas, as iniciativas ligadas à instalação de núcleos sob custódia da União são consideradas infrutíferas por grande parte dos políticos e fazendeiros, o que culminaria na falta de apoio governamental para a imigração quando Sinimbu assume o cargo de ministro da agricultura. Os cerca de 15 núcleos criados no Rio de Janeiro têm dois destinos: ou desaparecem antes mesmo dos anos 1870 ou se emancipam.

Nos anos 1880, mas principalmente a partir de 1890, a política imigratória é novamente reconfigurada em função dos conflitos políticos e econômicos decorrentes do fim da escravidão e da Proclamação da República ${ }^{37}$; eventos que colocam em xeque a questão da falta de braços e a queda expressiva da monocultura do café no Rio de Janeiro e em parte de Minas Gerais. No contexto conhecido como "política dos governadores", enquanto São Paulo e Minas Gerais iniciam uma agressiva fase de discriminação das terras e incentivo à "civilização dos indígenas", criando um número significativo de núcleos coloniais, o Rio de Janeiro, após encarniçadas disputas internas pelo controle político, lançava as bases de um plano de recuperação econômica no qual a questão do povoamento e desenvolvimento da policultura passam a compor a pauta de reivindicações. O discurso que enfatizava a necessidade

${ }^{33}$ É importante assinalar que as primeiras experiências com imigração estrangeira ocorrem nas duas décadas iniciais do século XIX estavam associadas à política de colonização de D. João VI.

${ }^{34}$ No ano de 1851, três ricos fazendeiros da província (o visconde de Baependy e os vereadores Braz Carneiro Belens e Nicolau Antonio Nogueira Valle Gama uniram-se a outros fazendeiros de Minas para contratarem na Europa famílias de colonos suíços ou alemães, dirigindo-se para esse fim ao ministro de Hamburgo, a quem remeteram instruções acompanhadas de instruções para se estabelecer o sistema de parceria. Os fazendeiros se comprometiam com o engajamento e o transporte dos colonos até o seu lugar de destino e o fornecimento de casas, sustento, vestuário emergencial até que os colonos estivessem em condições de adquirir com seus próprios recursos. De acordo com o ministro do império, o ministro de Hamburgo tinha dito que tinha conseguido engajar 146 famílias e que estas estavam prestes a chegar, ainda que tivesse sabido, através de uma publicação da Sociedade Colonizadora de Berlim, que tal operação tinha sofrido embaraços (Relatório do Presidente da Província do Rio de Janeiro, 1851).

${ }^{35}$ No qual estava inserido a ligação da referida região ao litoral do Espírito Santo e implantação de núcleos de imigrantes estrangeiros.

36 O ano 1855 marca o nascimento da « Associação Central de Colonização na Cidade do Rio de Janeiro » (ACC) que, ao associar interesses da iniciativa privada e pública, objetivava contratar 50.000 colonos em 5 anos. Sua direção era composta por representes do Rio de Janeiro e tinha Teóphilo Ottoni como sócio.

${ }^{37} \mathrm{E}$ nesse movimento não deixa de ser oportuno lembrar que as novas abordagens historiográficas assinalam como a questão da libertação dos escravos foi decisiva quando a República é deflagrada.

Caminhos de Geografia $\quad$ Uberlândia-MG $\quad$ v. 22, n. $81 \quad$ jun./2021 $\quad$ p. 127-149 Página 139


de aproveitar novas frentes de povoamento à base da policultura, pequena propriedade e emprego de mão de obra estrangeira é acolhido por lideranças mineiras em clara disputa aos projetos emanados pelos líderes da Zona da Mata, cujo sustentáculo político advinha de ganhos provenientes da monocultura cafeeira.

Com a fragilização dos acordos entre as elites mineiras e paulistas, e a posterior aproximação com políticos do Rio de Janeiro, o discurso sobre a necessidade de imigração é mais uma vez reconfigurado. Nessa perspectiva, as medidas "energéticas" - de corte liberal - adotadas pelas lideranças fluminenses inspiram as propostas de desenvolvimento de grupos políticos que almejam visibilidade em Minas Gerais. Este é o momento de nascimento de vários núcleos no estado, associado à ideia de modernização do campo, preparação da força de trabalho, miscigenação, higienização e diversificação da agricultura. No caso de Rio de Janeiro, além da grande obra de saneamento, cujo objetivo também era a de disponibilizar mais terras para a agricultura, alguns núcleos foram implantados.

É, portanto, neste contexto da crise política que a questão da imigração estrangeira se insere nas disputas envolvendo Rio de Janeiro, Minas Gerais e São Paulo. As propostas de recepção, povoamento e fixação de imigrantes estrangeiros e, depois, nacionais, acompanham de certa maneira as fases caracterizadas pela maior ou menor distensão política entre esses estados. $O$ trecho a seguir, retirado do periódico juiz-forano $O$ Pharol, ilustra um desses momentos. Atribuído ao colunista que utilizava o pseudônimo de Caio Graccho ${ }^{38}$ ele retrata, assim como autores outros, a aproximação paulatina de uma ala política de Minas Gerais em direção aos interesses fluminenses:

Em um de nossos artigos anteriores transcrevemos uma circular do illustre dr. Nilo Peçanha passando uma capina das camaras municipaes do Estado, que elle governa com o maximo criterio, economia e civismo. Aconselhava ali o presidente fluminense que as edilidades são corporações administrativas e devem exercer suas funcções isentas de politicagem, cuidando essencialmente dos interesses locaes. Insinuavamos ao nosso fleugmatico dr. Delfim Moreira que afinasse a planola do seu governo pelo mesmo diapasão, injectando nas veias das camaras mineiras bastas doses de brio e de civismo, para que o deixem em paz, livre dos seus engrossamentos espurios, ridiculos e hypocritas, constantemente publicados no ilegivel Minas Geraes (O PHAROL, 19.abril.1916, p.1).

Um dos aspectos notados neste excerto é um movimento que se acentua após a ascensão de Nilo Peçanha ao poder, qual seja a fragilização das relações entre os políticos mineiros e paulistas. Mas é necessário registrar que tal aproximação é seletiva, pois representava muito mais os interesses dos políticos da Zona da Mata.

Observem o que faz o dr. Nilo Peçanha no Estado do Rio: visita pessoalmente as principaes propriedades agricolas, animando aos lavradores com sua presença e conselhos; estimula o cultivo de toda e qualquer planta util e rendosa - o café, o fumo, a canna, as fructeiras, os vegetaes de fibras, para aproveitar todas os terrenos bons e ruins - inculcando medidas praticas e faceis; envia profissionaes aos agricultores que os peçam, para ensinaram no proprio logar da cultura os meios de a tornar mais viavel, productiva e rendosa com menor dispendio; distribue gratuitamente mudas, emxertos, sementes, instrumentos agrarios aos lavradores de poucos recursos, que hoje são quasi todos, lá, aqui, algures. Agora, no intuito de reanimar a lavoura fluminense, o seu presidente vae distribuir premios em dinheiro, tendo depositado, para esse fim exclusivo, a quantia de cem contos de réis no Banco Mercantil ( $O$ PHAROL, abril. 1916, p.1).

É possível notar nesta pequena parte da reportagem que durante a gestão de Nilo Peçanha inicialmente apoiador da política dos governadores - foi pensado além de formas para animar a lavoura, meios outros para atrair imigrantes aos seus respectivos estados. Isso explica a instalação dos primeiros núcleos - diretamente associadas à construção da nova capital de Minas Gerais, o florescimento de colônias agrícolas na década subsequente e a instalação de algumas estruturas de acolhimento (Ver Figura 1).

No caso do Rio de Janeiro, duas observações devem ser feitas para este mesmo período: a perda de prestígio como principal espaço de recepção e fixação de imigrantes, devido à existência hospedaria

${ }^{38}$ A informação sobre a existência pseudônimo é registrada na edição de 19 de janeiro de 1916, página 1, do jornal O Pharol. 
da llha da Flores ${ }^{39}$. Mesmo que tais fatores fossem ameaçados pelo clima de intensa competição com os estados de São Paulo e Minas Gerais, instalaram-se no estado novos imigrantes ${ }^{40}$, notadamente a partir dos anos 1900, quando então a longa crise política começa a apresentar sinais de seu fim. Não obstante, é nítido observar que a partir do final do século XIX, São Paulo se torna o maior receptor de imigrantes. Tal fato deve-se, em grande medida, à construção da hospedaria do Brás, que se tornou a maior da América Latina ${ }^{41}$. Esses e outros aspectos podem ser apreciados nos dados apresentados no quadro abaixo e interpretados a seguir.

Tabela 1 - População estrangeira residente nos estados, segundo censos - 1872, 1890, 1900, 1920.

\begin{tabular}{|c|c|c|c|c|}
\hline Estados & 1872 & 1890 & 1900 & 1920 \\
\hline Espírito Santo & 4.191 & 3.074 & 32.936 & 20.109 \\
\hline Minas Gerais & 46.900 & 46.787 & 141.647 & 88.013 \\
\hline Paraná & 3.697 & 5.153 & 45.134 & 63.110 \\
\hline Rio de Janeiro & 99.899 & 16.140 & 57.706 & 53.770 \\
\hline Rio G. do Sul & 41.725 & 34.765 & 140.854 & 154.623 \\
\hline Santa Catarina & 15.974 & 6.198 & 32.146 & 32.138 \\
\hline São Paulo & 29.622 & 75.030 & 529.187 & 833.709 \\
\hline
\end{tabular}

Recenciamento do Brasil, 1920, volume IV. In: Revista de Imigração e Colonização. Órgão oficial do Conselho de Imigração e Colonização, ANO I, No 2, abril, 1940. Rio de Janeiro, Brasil.

Conforme pode ser visto através dos dados dos Censos Demográficos, até 1870 o Rio de Janeiro figurava como o estado com maior contingente de estrangeiros no Brasil, ocupando São Paulo a quarta posição. Os ventos republicanos iriam alterar esse quadro, entre 1872 e 1890, sobretudo devido ao desenvolvimento do setor cafeeiro em São Paulo. Mais capitalizada, esse é o momento em que a elite paulista investe diretamente na introdução de imigrantes, criando sociedades, articulando-se a companhias, e instalando diversas infraestruturas, a exemplo da mencionada Hospedaria do Brás (1886). Os paulistas teriam sido os que melhor aproveitaram a janela de oportunidades entre os decênios de 1870 a 1880 em função da efervescência advinda das relações entre café e indústria, da solução imigrantista (que contribuía para a alargar a função das cidades), da constituição de mercado de terras em moldes capitalistas e da configuração de rede bancária mais avançada (GODOY, 2009) ${ }^{42}$.

39 Tal hospedaria, inaugurada em 1883, foi instalada nos últimos momentos do regime monárquico e, por isso, constitui-se numa experiência pioneira de recepção e abrigo dos imigrantes estrangeiros. Sua construção revela dois aspectos: a) o amadurecimento das estruturas de acolhimento existentes no Rio de Janeiro, que até então era o principal centro difusor de imigrantes; b) a então capacidade da referida província em impor, pelo menos por algum tempo, o seu poder político e econômico e de se transformar no principal centro difusor de imigrantes para todo país (CHRYSOSTOMO, VIDAL; 2014).

40 Nesse cenário, Lobo (1996) afirma que entre 1875 e 1890 e no decênio seguinte, 1890 e 1906-7, houve uma significativa entrada de imigrantes portugueses no estado do Rio de Janeiro, perfazendo um total de 274.972 para o primeiro período e 522.651 para o subsequente. Esse fluxo, no entanto, ficou grande parte retido na capital federal.

${ }^{41}$ A famosa hospedaria do Brás, a mais suntuosa do Brasil, foi construída em 1886 pela Sociedade Promotora de Imigração de São Paulo a partir de grande apoio financeiro do Estado. Embora ela chegasse a receber dez mil imigrantes por dia, em seu projeto inicial previa-se o acolhimento somente de quatro mil. Existiam, anteriormente, no estado, as hospedarias de Ponte Grande de Sant'Ana (que funcionou entre 1877 e 1880), a hospedaria de Bom Retiro e a do Campo Grande da Luz (PAIVA e MOURA, 2008). A esse respeito ver: SANTOS, Ivison Poleto dos. O Público e o Privado nas Sociedades de Imigração: o caso da Sociedade Promotora de Imigração (1886 a 1895): In: Sociedade em Debate, Pelotas, 14(2): 55-69, jul.-dez./2008.

${ }^{42}$ Mas, na contramão desse cenário favorável, em Minas Gerais havia um modelo político centralizado e com acirradas disputas das elites regionais. O ethos patrimononialista e o clientelismo, com efeito, turvavam a visão 
Para Lobo (1996), os debates que colocam em cena o florescimento da economia paulista e a estagnação do Rio de Janeiro, no período de 1900 a 1920, estariam atrelado ao papel da oferta da mão-de-obra e ao perfil técnico dos imigrantes estrangeiros ${ }^{43}$.

Os mineiros, por sua vez, detinham o mais vultuoso sistema escravista regional do país e, por extensão, a economia mais dinâmica. A então província respondia pela segunda economia cafeeira do Brasil e possuía uma desenvolvida economia de subsistência mercantil. Seu setor de atividades industriais apresentava-se proeminente em virtude, sobretudo, do vigor das indústrias têxtil, de siderurgia e transformação de gêneros da agropecuária. Possuíam ainda o mais pujante mercado consumidor, uma vez que a população na província era a maior do Império. Essas e outras condições - como a abundância de matérias primas necessárias ao processo industrial - conferiam a Minas Gerais condições ideais para o desenvolvimento regional.

A adesão política de paulistas, mineiros e parte das elites da província do Rio de Janeiro aos processos que redundaram na Proclamação da República deu continuidade a esse cenário de dominância econômica de São Paulo e manteve Minas Gerais na segunda posição44. Em termos de população estrangeira, a liderança dos paulistas permanece inalterada até 1920 devido à continuidade de sua política de financiamento de transporte e fixação de imigrantes, iniciada em 1886, e que é amparada por capitais públicos e privados advindos dos grandes fazendeiros. Em Minas, talvez como resposta à diminuição do fluxo de imigrantes (de 141.647 para 88.013), é no período de 1900 e 1920 que se implantam o maior número de núcleos coloniais (Ver Figura 1). Talvez tenha sido uma estratégia para incrementar sua economia que assistia o declínio da lavoura cafeeira e a evasão dos trabalhadores para as fazendas de café em São Paulo. Nesse ínterim, a perda da população estrangeira no Rio de Janeiro refletia tanto a retração de investimentos públicos neste setor, como a desmobilização dos setores privados, o que a explicaria a posição inferior comparada aos estados de Minas Gerais e São Paulo.

Ao fim e ao cabo, em Minas Gerais, que atuava como "fiel da balança" durante a República, foram fundados cerca de 37 núcleos de colonização, sem falar nas terras oferecidas por algumas municipalidades para tal fim, mas que por motivos diversos não foram aproveitadas para a instalação de colônias. No Rio de Janeiro, notáveis investimentos foram feitos, mas o governo encontrou dificuldades de implantar núcleos, de forma que apenas 7 foram fundados nesse período. Associados à política imigratória, sublinhamos a construção de diversas estruturas de acolhimento, que se tornaram alvo de conflitos em torno da centralização do serviço de recepção, acolhimento nos estados e distribuição de imigrantes. É nesse âmbito que podemos compreender o papel que teve a rede de hospedarias instaladas, sobretudo, nas regiões sudeste e sul - Ilha das Flores, no Rio de Janeiro; Brás, em São Paulo e Horta Barbosa ${ }^{45}$, em Juiz de Fora. Como reflexo dos conflitos intrarregionais, assistiuse a implantação de pequenas hospedarias, albergues, armazéns, casas e hotéis próximos aos portos e estradas de ferro localizada no interior dos estados (Ver Figuras 1 e 2). Atuando como objeto de valorização do espaço, o florescimento, a partir de 1890, desses vários dispositivos tinha o objetivo explícito de fixar o imigrante às localidades próximas, evitando, assim, sua evasão para outras cidades

das elites e políticos para as potencialidades da economia regional. Poucos eram os empresários industriais que conseguiam se desfazer dos símbolos tradicionais e esboçar visão empreendedora moderna. O poder seguia tendo como métrica o domínio sobre a terra e a população rural. Dessa forma, o que se assistia eram projetos voltados a interesses pessoais, sem uma visão regional mais ampla (GODOY, 2009).

${ }^{43}$ Nesse contexto, entre os anos de 1882 e 1934, cerca de 4,5 milhões de pessoas se dirigiram para o país, dos quais 2,3 milhões se instalaram no estado de São Paulo (FAUSTO, 1999).

44 O movimento demográfico observado até 1920, demonstra que a imigração mais intensa ocorreu a partir de 1890 e dirigiu-se para São Paulo e Rio Grande do Sul, em decorrência do financiamento do transporte marítimo e à política de colonização. Ela explica a entrada relativamente numerosa de agricultores nos estados de Espírito Santo, Santa Catarina, Minas Gerais e Paraná.

45 Trata-se da maior hospedaria mineira inaugurada em 1888 e instalada, estrategicamente, em cidade próxima ao Rio de Janeiro, o que facilitava o deslocamento dos imigrantes do porto desta cidade até Minas Gerais. Tamanha era sua importância que "os demais estabelecimentos congêneres - de dimensões mais modestas eram descritos como "derivativos à grande hospedaria de Juiz de Fóra" (MINAS GERAES, 15.NOV.1896, p.6 ).

$\begin{array}{lllll}\text { Caminhos de Geografia } \quad \text { Uberlândia-MG } & \text { v. 22, n. } 81 \quad \text { jun./2021 } & \text { p. 127-149 Página } 142\end{array}$ 
e estados.

A presença dessas estruturas no território contribuiu para a criação de novas centralidades, sobretudo porque os locais que as dispunham eram os que recebiam ou receberiam mais recursos para se candidatarem ao papel de municípios receptores de imigrantes. Não ao acaso, os estados criaram "regiões propícias à imigração", como foi o caso em Minas Gerais dos decretos que instituíram distritos de imigração, como no Rio de Janeiro quando definiram-se zonas e locais mais aptos a receber imigrantes (Ver Figuras 1 e 2).

Ideias de centralidade, associadas aos "braços europeus", comporiam também o enredo discursivo empregado na era republicana para justificar as propostas de modernização de cidades e regiões de Belo Horizonte e Rio de Janeiro. Assim, recursos endereçados ao ingresso de imigrantes estrangeiros vincularam-se àqueles destinados à construção da Cidade de Minas (Belo Horizonte). Dois tipos de imigrantes integrariam a primeira leva que chegou na recém construída capital: aqueles que se situaram nas franjas suburbanas da cidade em núcleos de colonização implantados para o abastecimento e os que trabalharam em diferentes ofícios nas obras de construção da nova capital.

Os debates travados ao redor mudança da capital nos dois estados no começo da era republicana evidenciam aspectos semelhantes na medida em que tanto em Minas Gerais como no Rio de Janeiro, a questão do povoamento e ingresso de imigrantes estrangeiros foi adicionada como importante ingrediente para justificar as propostas de mudança ${ }^{46}$. Em meio à crise política ${ }^{47}$, as lideranças argumentavam que a vinda de imigrantes para as cidades e para o campo infundiria o progresso, recolocando em pauta as diferentes propostas desenvolvimento agrícola, comercial e industrial a partir do impulso da imigração espontânea em seus respectivos estados.

Como discutido, a necessidade de saneamento em função da proliferação de epidemias, como a febre amarela, malária, cólera obrigou a definir uma série de medidas administrativas que fizeram recrudescer a discussão sobre os imigrantes ideais e quais áreas/setores estes seriam destinados. Atentos a essas exigências, tanto os políticos do Rio de Janeiro como Minas Gerais passaram a admitir a possibilidade de contratar orientais em observância às características da paisagem. Tendo como um dos principais trunfos a questão do clima, Quintino Bocaiuva, ideólogo e político ${ }^{48}$, era um dos maiores defensores da entrada dos chins no Brasil. Nessa medida, alvo de preconceitos durante um longo período, tais grupos passaram a ser aceitos quando se diagnosticou que se adaptariam ao trabalho em regiões com temperaturas elevadas.

Não deixa de ser oportuno mencionar que as representações de "paisagens sãs e enfermas" ligadas aos imigrantes, foram fundamentadas por discursos evolucionistas de caráter geográfico, que

${ }^{46} \mathrm{Em}$ um momento de crise política e discussões sobre os rumos do partido republicano fluminense, tal debate foi atiçado quando os seguidores de Francisco Portela, influente político e morador de Campos, recolocam necessidade de mudar a capital. Neste enredo, os argumentos contrários e favoráveis a tal mudança para o interior, envolvendo a cidade de Campos, Nova Friburgo e Niterói foram amplamente divulgados pelos jornais (ALVES, 2009 CHRYSOSTOMO, 2011)

${ }^{47}$ Não deixa de ser oportuno lembrar que em 1891, o Congresso é fechado pelo marechal Deodoro da Fonseca, instaurando uma crise política que levou a sua renúncia neste mesmo ano, e a posse de Floriano Peixoto. Neste contexto, em 1894 a capital foi transferida para Petrópolis em função do conflito armado contra Floriano Peixoto que durou 1893 até março de 1894. Em 1903, Nilo Peçanha, ligado ao grupo político de Floriano Peixoto, e adepto à política dos governadores, se candidata e vence a eleição para presidente do estado do Rio de Janeiro.

${ }^{48}$ A atuação política e ideológica de Quintino Bocaiuva na história da imigração do Brasil e do Rio de Janeiro em particular é ilustrada pelo seu envolvimento desde os anos $1860 \mathrm{em}$ empresas que tinham o propósito de trazer imigrantes estrangeiros para o Brasil, na sua participação como redator de jornal e impulsionador da campanha republicana, assim como em sua adesão à Libertação dos escravos. Sob tais perspectivas, o acervo da Fundação Getúlio Vargas (CPDC) fornece diversas fontes que comprovam a importância de Quintino Bocaiuva, ao assinalar as seguintes funções exercidas em sua vida política: "diretor de "O Diário do Rio de Janeiro" (1865); organizador do serviço de colonização do Brasil para a Sociedade Brasileira de Imigração, que era sediada nos Estados Unidos (1866-1867); colaborador em diversos periódicos e proprietário de "O País"; autor de vários livros, destacando-se "Estudos críticos e literários" (1858), "Os mineiros da desgraça" (1861), "Os nossos homens, retratos políticos e literários" (1864) e "A crise da lavoura" (1868)". Disponível em: < https://cpdoc.fgv.br/sites/default/files/verbetes/primeira-republica/BOCAIUVA,\%20Quintino.pdf>.

$\begin{array}{lllll}\text { Caminhos de Geografia } & \text { Uberlândia-MG } & \text { v. 22, n. } 81 & \text { jun./2021 } & \text { p. 127-149 Página } 143\end{array}$



Higor Mozart Geraldo Santos

elegeriam regiões imigratórias em função do clima, altitude e relevo, mas também pela densidade de estruturais materiais, como é possível verificar na fala do presidente do estado do Rio de Janeiro nos 1910.

O governo cuidou igualmente dos serviços concernentes ao saneamento da Baixada e a Colonisação (...) Era sua intenção aproveitar nos planaltos colonos europeus e nas baixadas colonos japoneses. Com esse objectivo adquirio terras apropriadas á colonisação fazendo medir e demarcar por profissionais competentes as devolutas de propriedade do Estado (...) Relatório do Presidente da Província, 1910, p. 7).

A ideia de resolver os problemas das "paisagens enfermas", inicialmente propalado como um obstáculo à recepção de imigrantes e ao desenvolvimento das cidades, ao se deslocar para o meio rural associou a cura de diversos males à construção de núcleos coloniais. Assim, ao se instaurar o debate sobre modernização do campo, um dos temas recorrentes que justificariam as propostas de imigração relacionou-se ao saneamento das franjas urbanas, como foi o caso da baixada fluminense no Rio de Janeiro e da Zona da Mata, em Minas Gerais. Esse é um aspecto que podemos observar no pronunciamento do político juiz forano, Raul Penido, ao discursar sobre a viabilidade de projeto de saneamento para a Zona Mata: "O saneamento da matta é uma questão que deve pertencer unica e exclusivamente ao Estado, é uma questão, poderei dizer [...] universal, porque universal é a nossa vida" (MINAS GERAES, 17.jul.1896, p.2).

Não podemos deixar de mencionar que a questão do saneamento extravasou para o campo racial e acionou várias teorias, entre quais a de corte evolucionista, que pregava a assimilação dos índios, caboclos e negros via cruzamento com a raça branca; leia-se, através da penetração do imigrante estrangeiro nos sertões. Ao associar vadiagem e a indolência à produtividade e à questão racial, esses grupos passaram a ser vistos como um empecilho ao progresso, sendo estigmatizados e muitas vezes excluídos das propostas de melhoria esboçadas para diferentes regiões. Nessa medida, a transmutação para a condição de nacional, via miscigenação, foi pensada como um mecanismo para promover a "melhoria étnica", como ocorreu na colônia de Itambacuri, uma das mais importantes do estado de Minas Gerais, e que anteriormente era um aldeamento indígena ${ }^{49}$.

Em termos comparativos, portanto, assinalamos que a política de imigração nos dois estados tem ações muito semelhantes, mas guardam especificidades em relação aos caminhos adotados para atrair, distribuir e instalar os estrangeiros e nacionais em cada contexto. Dessa forma, entre o final do XIX até os anos 1930, aliado à ideia de diminuir os incentivos à imigração subvencionada e estimular a imigração espontânea, propostas como policultura, ensino agrícola, saneamento do campo, mestiçagem, investimento em estradas, entre outras, tornam-se predominantes. Planos urbanos e remodelações de cidade em áreas centrais e no interior foram utilizados também para justificar a necessidade de mão de obra qualificada visando à modernização.

Nesse sentido, apesar da discrepância numérica em relação aos núcleos coloniais fundados nos dois estados, assinalamos que não existiam projetos notoriamente distintos. $O$ que efetivamente marcou diferença entre Minas Gerais e Rio de Janeiro foram os caminhos percorridos para resolver a crise política e econômica nos respectivos estados.

\section{CONSIDERAÇÕES FINAIS}

Quisemos indagar como a questão migratória é uma variável importante para explicar as disputas por recursos empreendidas entre Rio de Janeiro e Minas Gerais frente ao poderio de São Paulo durante a Primeira República. Os discursos regionais relacionados à vinda e à instalação dos imigrantes consolidaram determinadas imagens do patrimônio geográfico; manipuladas para promover a integração física e econômica de lugares. Este processo, sem dúvida, elegeu projetos imigratórios considerados adequados a partes seletas do território. De certa maneira, a vinda e acolhimento dos

49 Ver a esse respeito Amoroso (2014).

Caminhos de Geografia

Uberlândia-MG v. 22, n. 81

jun./2021 p. $127-149$

Página 144 

Higor Mozart Geraldo Santos

estrangeiros e a construção de dispositivos espaciais revelaram novas tensões em torno da captação de recursos governamentais, evidenciando outras nuances dos conflitos regionais.

Os discursos imigrantistas, que ecoam das principais ideias fisiocratas, ressaltavam a necessidade de aproveitar, via trabalho, a vastidão de recursos latentes. Os enunciados muito se aproximavam das ideias geográficas sobre relação homem meio e os processos de aculturação, o que nos permite dizer, sem, no entanto, afirmar, que alguns de seus propagadores, dialogavam com os postulados da escola determinista e possibilista.

A partir dos indícios deixados nos discursos e práticas sobre imigração procuramos comparar as políticas migratórias em um contexto de transformação política, regulamentação das terras devolutas e redefinição dos papéis dos entes federativos. Diante da importância de São Paulo, notamos um manifesto desejo das elites mineiras em se igualar a este estado. Suas soluções estavam calcadas numa visão temporal no qual a sensação de letargia traduzia-se na ideia de sub-aproveitamento do solo e na proposta do desbravamento dos sertões. No caso do Rio Janeiro, esse desejo aparece dissimulado em outras propostas de modernização que não almejavam, necessariamente, se igualar a São Paulo, embora, em alguns casos, esse projeto integrasse a pauta de certos setores agrários. Como antigo celeiro do Império e mantendo ainda o título de capital da República, a mais ambiciosa aspiração das elites fluminenses era a recuperação de seu prestígio político e econômico.

Desde de Diegues Júnior (1967), análises enlaçando a questão da imigração à urbanização do território são recorrentes, no entanto, o mesmo não pode ser dito em relação aos parcos estudos empíricos a respeito dos processos de negociação das terras dos núcleos coloniais. Pouco se estudou sobre o destino das terras dos núcleos quando de sua emancipação ou extinção, ou seja, os aspectos relacionados à transformação da estrutura fundiária em âmbito local e regional como desdobramento da política migratória. É notório perceber, no entanto, que quando um núcleo colonial é implantado ele resulta, em um primeiro momento, da compra de uma ou mais fazendas, que são desmembradas e parceladas. Nesses novos embriões de cidade, são destinadas áreas urbanas e rurais, instaladas estradas, escolas, eletricidade, água e, por vezes, postos de saúde e correios, o que gera um impacto sem precedentes nas áreas próximas e distantes de onde são inseridos.

O que fica demarcado no contexto republicano em relação à política imigratória, é a reestruturação do espaço agrário e a reedificação do papel das cidades e regiões. Nesse sentido, na tentativa de solucionar a alegada falta de braços e a perda de prestígio político, os governos de Minas Gerais e Rio de Janeiro acionaram medidas que apresentavam os seguintes pontos comuns: a) o saneamento das cidades e seu deslocamento para as áreas rurais; b) a alocação de recursos e definição de áreas prioritárias para o investimentos em infraestruturas voltadas para receber imigrantes estrangeiras; c) a densificação de dispositivos, com destaque às ferrovias, associadas à criação de colônias agrícolas; d) a reestruturação do setor administrativo voltado à demarcação de terras; e) o reforço do ensino agrícola em todos níveis.

Em síntese, tais medidas redefiniram o papel de algumas cidades e, por conseguinte, criaram uma nova paisagem, mais esquadrinhada, e que refletia o maior domínio técnico da sociedade sobre a natureza. Ângulos e linhas marcam o desenho dessa nova paisagem; ferramentas e máquinas, o alvorecer de novas técnicas de produção; escolas e demais instituições, outras possibilidades de ser e pensar o campo na sua interface com o mercado urbano. Esses elementos davam vazão à uma nova racionalidade instrumental cujas sementes deram florescimento a uma outra "paisagem política" (BESSE, 2014). As feições dessa paisagem nasceriam dos "gestos territoriais" empreendidos por atores hegemônicos. Gestos esses que se manifestariam por meio diversas práticas espaciais: parcelamento e desmembramento do solo, delimitação de núcleos, povoamento, criação de hospedarias, instalação de ferrovias, escolas e demais infraestruturas. Nesse sentido, essa paisagem, adjetivada como política, expressaria as representações espaciais de grupos distintos: a) a do Estado, que almejava um maior controle das terras, o incremento das atividades agrícolas, povoamento dos 

Higor Mozart Geraldo Santos

sertões e a presença de população mestiça e civilizada nos núcleos ${ }^{50}$; b) a do grande proprietário fundiário, cujo sonho, mesmo com nuances diferenciadas, era tornar a terra mais produtiva, ampliando seus lucros; c) e, finalmente, a dos lavradores (colonos, imigrantes, nacionais ou estrangeiros) em ter uma vida digna, um naco de terra e prosperar. Tratar-se-ia de uma luta, protagonizada por diferentes atores que objetivavam, converter a paisagem sertaneja em uma paisagem efervescente e dinâmica.

\section{FONTES PRIMÁRIAS}

Periódicos

A VERDADE. A Verdade. Cidade de Itajubá, 26 de agosto de 1886. Disponível em: $<$ http://memoria.bn.br/DocReader/848131/93 >. Acesso em: 9.mai.2020.

DIÁRIO DE MINAS. Estado da Lavoura. Juiz de Fora, 1ํ de agosto de 1888. Disponível em: < http://memoria.bn.br/DocReader/DocReader.aspx?bib=373460\&PagFis=69>. Acesso em: 8.jun.2015.

MINAS GERAES. A Immigração em Minas. Ouro Preto, 5 de Agosto de 1894, p. 5. Disponível em: $<$ http://memoria.bn.br/DocReader/DocReader.aspx?bib=291536\&PagFis=4864>. Acesso em 08. Set. 2014.

A Italia em Minas Geraes. Ouro Preto, 1 de Outubro de 1895. Disponível em: <http://memoria.bn.br/DocReader/DocReader.aspx?bib=291536\&PagFis=7794>. Acesso em: 02 mar. 2013.

Camara dos Deputados - 15 Sessão Ordinária aos 7 de julho de 1896. Ouro Preto, 17 de julho de 1896. Disponível em: < http://memoria.bn.br/DocReader/291536/9839>. Acesso em: 23.mar.2019.

Congresso Mineiro - Camara dos Deputados. Ouro Preto, 21 de julho de 1899. Disponível em: <http://memoria.bn.br/DocReader/DocReader.aspx?bib=291536\&PagFis=16661>. Acesso em: 22. dez. 2014.

\section{Discurso pronunciado na sessão de 20 de maio de 1895 - Serviço de Immigração.}

Ouro Preto, 5 de junho 1895. Disponível em: <http://memoria.bn.br/DocReader/DocReader.aspx?bib=291536\&PagFis=6832>. Acesso em: 23. jul. 2104.

Minas Geraes na Italia. Ouro Preto, 2 de Novembro de 1895. Disponível em: <http://memoria.bn.br/DocReader/DocReader.aspx?bib=291536\&PagFis=8036>. Acesso em: 20. out. 2015.

Pareceres. Ouro Preto, 9 de setembro de 1898. Disponível em:

$<$ http://memoria.bn.br/DocReader/DocReader.aspx?bib=291536\&PagFis=15009>. Acesso em: 08 set. 2014.

Publicação. Ouro Preto, 28 de janeiro de 1898, p.2. Disponível em: <http://memoria.bn.br/DocReader/DocReader.aspx?bib=291536\&PagFis=13695>. Acesso em: 18. mai. 2014.

O ESTADO DE MINAS GERAES.. Ordem do dia. Ouro Preto, 20 de novembro de 1891. Disponível em: <http://memoria.bn.br/DocReader/DocReader.aspx?bib=305367\&PagFis=337>. Acesso em: 15.jun.2015.

O PHAROL. Immigração. Juiz de Fora, 12 de fevereiro de 1891. Disponível em:

50 Os núcleos criados são espaços de experimentação das teses que advogavam o branqueamento da população. Tratava-se, portanto, de uma paisagem composta por imigrantes brancos, o que representava o enfraquecimento de outros projetos de integração social, isto é, uma vitória da ética do trabalho. Ao educarem os corpos através de diversos dispositivos (escolas, núcleos agrícolas, colônias correcionais, campos experimentais, igrejas, clubes, práticas culturais etc) essas paisagens produziriam iconografias, instaladas ou imaginadas, que disciplinavam os grupos considerados indolentes e que estavam aquém do ritmo do progresso desejado. 
$<$ http://memoria.bn.br/DocReader/DocReader.aspx?bib=258822\&PagFis=7741 >. Acesso em: 30.nov.2015.

Bello Exemplo. Juiz de Fora, 15 de fevereiro de 1916. Disponível em: <http://memoria.bn.br/docreader/258822/33820>. Acesso em: 23.jul.2017.

.Immigração. Juiz de Fora, 18 de novembro de 1885. Disponível em: <http://memoria.bn.br/DocReader/DocReader.aspx?bib=258822\&PagFis=3453>. Acesso em: 27.nov.2015.

Medidas Práticas. Juiz de Fora, 19 de abril de 1916. Disponível em: $<$ http://memoria.bn.br/DocReader/258822/34036?pesq=immigração $>$. Acesso em: 23.jul.2018.

Sem título. Juiz de Fora, 19 de janeiro de 1916. Disponível em: < http://memoria.bn.br/docreader/258822/33728>. Acesso em: 23.jul.2018.

O IMMIGRANTE, São Paulo, n. 1, ano 1, jan. 1908, capa. Apesp.

Mensagens

Ministério da Agricultura (1895)

Mensagem do Presidente de Minas Gerais (1890-1920)

Mensagem do Presidente do Rio de Janeiro (1890-1916)

Mensagem enviada à Assembléa Constituinte do Estado do Rio de Janeiro pelo presidente Dr. José Thomaz da Porciuncula na 3 a e ultima sessão ordinária da 1 a Legislatura, 1 o de agosto de 1893. Rio de Janeiro. Typ).

Outros

Boletim da Sociedade de Geographia do Rio de Janeiro - 1885 a 1948 - PR-SOR-02757-181897

Recenciamento do Brasil, 1920, volume IV. In: Revista de Imigração e Colonização. Órgão oficial do Conselho de Imigração e Colonização, ANO I, № 2, abril, 1940. Rio de Janeiro, Brasil.

\section{FONTES SECUNDÁRIAS}

ABREU, Maurício de Almeida. "Pensando a cidade no Brasil do passado". In: Silva, José

Borzacchiello da; Costa, Maria Clélia Lustosa; Dantas, Eustógio Wanderley Correia (org.). A cidade e o urbano. Fortaleza: Universidade Federal do Ceará, (1997). pp. 27-54.

Construindo uma Geografia do Passado: Rio de Janeiro, cidade portuária, século XVII. GEOUSP Espaço e Tempo (Online), [S. I.], v. 4, n. 1, p. 13-25, 2000.

AMOROSO, Marta. Terra de índio:, imagens em aldeamentos do Império. São Paulo: Terceiro Nome, 2014.

ALVES, H. M. A Sultana do Paraíba - Reformas urbanas e poder político em Campos dos

Goytacazes, 1890-1930. Rio de Janeiro: Arquivo Público do Estado do Rio de Janeiro, 2009.

BESSE, Jean-Marc. O gosto do mundo: exercícios de paisagem. Rio de Janeiro (RJ): UERJ, 2014.

CHRYSOSTOMO, Maria Isabel de Jesus. Campos: a capital sonhada de uma província desejada (1835-1897). Revista História. História vol.30 no.1 Franca Jan./June 2011. Disponível em https://www.scielo.br/scielo.php?script=sci arttext\&pid=S0101-90742011000100004. https://doi.org/10.1590/S0101-90742011000100004

e VIDAL, Laurent. Do depósito à hospedaria de imigrantes: gênese de um "território da espera" no caminho da emigração para o Brasil. Hist. cienc. saude-Manguinhos [online]. 2014, vol.21, n.1, pp.195-217. Epub Feb 17, 2014. ISSN 0104-5970. https://doi.org/10.1590/S0104$\underline{59702014005000008}$

BARBOSA, Daniel Henrique Diniz. Tecnoburocracia e pensamento desenvolvimentista em Minas Gerais (1903-1969). Tese (Doutorado) - Faculdade de Filosofia, Letras e Ciências Humanas da 
Universidade de São Paulo, São Paulo, 2012.

COSTA, Milene Ribas. A Implosão da Ordem: a Crise Final do Império e o Movimento Republicano Paulista. Dissertação de Mestrado em Ciência Política da Faculdade de Filosofia, Letras e Ciências Humanas da Universidade de São Paulo, 2006.

DULCI, O. João Pinheiro e as origens do desenvolvimento mineiro. In: GOMES, Ângela de Castro (org.). Minas e os fundamentos do Brasil moderno. Belo Horizonte: Editora UFMG, 2005.

FAUSTO, Boris (Org.). Fazer a América: a imigração em massa para a América Latina. São Paulo: Edusp. 1999.

FERREIRA, Marieta de Moraes (Coord.) A República na velha província. Rio de Janeiro: Rio Fundo, 1989.

GARCIA, N. Jr. O que é propaganda ideológica. [S. I.]: Nobel, 1982. (Coleção primeiros passos).

HOLANDA, S. B. Visão do Paraíso. 2aㅡ Ed. rev, e amp. São Paulo: EDUSP/Nacional, 1969, prefácio à $2^{\mathrm{a}}$ ed.

IGLÉSIAS, Francisco. Política econômica do Estado de Minas Gerais, 1890-1930. In: SEMINÁRIO DE ESTUDOS MINEIROS, 5, Belo Horizonte, UFMG, 1982.

IGLÉSIAS, Francisco. Política Econômica do Governo Provincial Mineiro (1835-1889), Rio de Janeiro: Ministério da Educação e Cultura, Instituto Nacional do Livro, 1958

KLEIN, H. S. Migração internacional na história da América. In: FAUSTO, B. (org). Fazer a

América. São Paulo: EDUSP, 2000. p. 13-31.

LOBO, Maria Eulália Lahmeyer. A imigração Portuguesa e a Mão de Obra do Rio de Janeiro na Primeira República. In: História Econômica da Primeira República. São Paulo: Editora Hucitec/ Fapesp/ Associação Brasileira de Pesquisadores em História Econômica, 1996.

MONTEIRO, N. G. Imigração e Colonização em Minas: 1889-1930. Belo Horizonte: Imprensa Oficial, 1973.

Dicionário biográfico de Minas Gerais (período republicano 1889-1991). Belo Horizonte: Assembléia Legislativa de Minas Gerais, 1994.

MORAES, Antônio Carlos Robert. Território e História no Brasil. São Paulo: Ed. Hucitec, 2002.

OLIVEIRA, Márcio de. Origens do Brasil meridional: dimensões da imigração polonesa no Paraná, 1871-1914. Estud. hist. (Rio J.), Rio de Janeiro, v. 22, n. 43, p. 218-237, June 2009 . Available from <http://www.scielo.br/scielo.php?script=sci_arttext\&pid=S0103-

$21862009000100012 \&$ Ing=en\&nrm=iso $>$. access on 10 Oct. 2016. https://doi.org/10.1590/S010321862009000100012

PAIVA, Odair da Cruz, MOURA, Soraya, Hospedaria de imigrantes de São Paulo, São Paulo, Paz e Terra, 2008.

PETRONE, Maria Tereza Schorer. Imigração in FAUSTO, B. História Geral da Civilização Brasileira. TOMO III (O Brasil Republicano), 2º volume, cap.III. Difel, $2^{\underline{a}}$ ed. São Paulo, 1978.

PHILO, Chris. "História, geografia, e o 'mistério ainda maior' da história da geografia histórica. In: Gregory, Derek; Martin, Ron; Smith, Graham (Org.) (1996). Geografia Humana: Sociedade, espaço e ciência social. Rio de Janeiro: Jorge Zahar Editor, pp. 269-298, 1996.

SANTOS, Ivison Poleto dos O Público e o Privado nas Sociedades de Imigração: o caso da Sociedade Promotora de Imigração (1886 a 1895): In: Sociedade em Debate, Pelotas, 14(2): 55-69, jul.-dez./2008.

SANTOS, Milton. Natureza do Espaço: Técnica e Tempo. Razão e Emoção. São Paulo: Editora da Universidade do Estado de São Paulo, 2006. 
VASCONCELLOS: Pedro de Almeida em "Questões metodológicas na geografia urbana histórica. In: GeoTextos, vol. 5, n. 2, dez 2009. https://doi.org/10.9771/1984-5537geo.v5i2.3791

VERSIANI, flávio Rabelo e VERSIANI, Maria Teresa R. O. A industrialização brasileira antes de 1930: uma contribuição. In: VERSIANI, flávio R. MENDONÇA DE BARROS, José R. (org.) Formação Econômica do Brasil. A experiência da industrialização. São Paulo: Saraiva, 1977 (Série ANPEC de Leituras de Economia).

VIDAL, Laurent; CHRYSOSTOMO, Maria Isabel de Jesus. Une histoire oubliée: l'association centrale de colonisation de Rio de Janeiro et la marchandisation de l'émigration européenne (1857-1865). In: Poton, Didier; Symington, Micéala; Vidal, Laurent (Org.). La migration européenne aux Amériques: pour un dialogue entre histoire et littérature. Rennes: Presses Universitaires de Rennes. p.23-39. 2012. https://doi.org/10.4000/books.pur.26005

Recebido em: 04/06/2020

Aceito para publicação em: 20/01/2021 